\title{
Effect of Sodium Chloride on Subsequent Survival of Staphylococcus aureus in Various Preservatives
}

\author{
Bayan M. Abu-Ghazaleh \\ Department of Biology and Biotechnology, Hashemite University, Zarqa, Jordan \\ Email: bay.ghaz@yahoo.com
}

How to cite this paper: Abu-Ghazaleh, B.M. (2016) Effect of Sodium Chloride on Subsequent Survival of Staphylococcus aureus in Various Preservatives. Food and Nutrition Sciences, 7, 955-963.

http://dx.doi.org/10.4236/fns.2016.711094

Received: August 16, 2016

Accepted: September 9, 2016

Published: September 12, 2016

Copyright $\odot 2016$ by author and Scientific Research Publishing Inc. This work is licensed under the Creative Commons Attribution International License (CC BY 4.0).

http://creativecommons.org/licenses/by/4.0/

\begin{abstract}
Chemical preservatives in foods are nowadays added at lower concentrations. However, this may allow survival of bacterial cells and induce increased resistance to various preservatives. In this study, the effects of growth in $\mathrm{NaCl}(10 \%$ or $15 \%)$ on survival of Staphylococcus aureus strains in various chemical and physical preservatives were investigated. Growth of the strains for $20 \mathrm{~h}$ at $37^{\circ} \mathrm{C}$ in nutrient broth containing $10 \% \mathrm{NaCl}$ enhanced survival in chemical preservatives (e.g. nutrient broth containing $20 \% \mathrm{NaCl}$, or $0.3 \%$ thyme extract, or $0.1 \%$ ascorbic acid). Growth at $37^{\circ} \mathrm{C}$ for 20 $\mathrm{h}$ in nutrient broth containing $15 \% \mathrm{NaCl}$ or for $5 \mathrm{~d}$ in nutrient broth containing $10 \%$ $\mathrm{NaCl}$ greatly enhanced survival of the strains in the tested preservatives. For survival at low temperature $\left(5^{\circ} \mathrm{C}\right.$ ) (physical preservative), cells grown at $37^{\circ} \mathrm{C}$ for $20 \mathrm{~h}$ in nutrient broth containing $10 \% \mathrm{NaCl}$ were not more tolerant to low temperature. Growth of the strains at $37^{\circ} \mathrm{C}$ for $20 \mathrm{~h}$ in nutrient broth containing $15 \% \mathrm{NaCl}$ or for $5 \mathrm{~d}$ in nutrient broth containing $10 \% \mathrm{NaCl}$ only slightly increased the survival of cells at low temperature.
\end{abstract}

\section{Keywords}

$\mathrm{NaCl}$, Staphylococcus aureus, Preservatives

\section{Introduction}

Staphylococcus spp., especially $S$. aureus, is the second most common cause of food borne diseases worldwide [1] [2]. It has been reported that in USA, for example, the estimated number of cases of staphylococcal gastroenteritis is $1-2$ million per year [3]. The symptoms of staphylococcal gastroenteritis usually develop after 1 - 6 hours after ingestion of contaminated food, and include nausea, vomiting, diarrhea and abdominal cramps. About $10 \%$ of the affected persons may be admitted to hospital but the mortality rate is very low or nil [3]. Staphylococcal gastroenteritis results from consumption 
of one or more preformed heat-resistant enterotoxins that are produced in food contaminated with staphylococcus [4]. The amount of enterotoxin necessary to cause gastroenteritis in humans is very small. It has been reported that, in an outbreak of staphylococcal food poisoning due to chocolate milk, the mean amount of staphylococcal enterotoxin A in a 400-ml container was $144 \mathrm{ng}$ [5].

$S$. aureus is relatively resistant to drying and high temperature (it withstands $50^{\circ} \mathrm{C}$ for $30 \mathrm{~min}$ ). It grows well in media containing $9 \% \mathrm{NaCl}$, and some strains can grow in media containing higher concentrations of sodium chloride [6]. Food borne outbreaks of $S$. aureus are usually associated with food products that are made by hand and not properly refrigerated after preparation. The most important vehicle foods include meat, chicken, milk, and their products [1].

Chemical preservatives are usually added to prevent spoilage of food and extend its shelf life. Because consumers prefer minimally processed foods, chemical preservatives are nowadays added at lower concentrations. However, some bacterial cells may survive in the food and this stress may induce increased resistance to various conditions. To my knowledge, there are no studies on the response of $S$. aureus to these conditions. Therefore, this study was conducted to investigate the effects of growth of $S$. aureus strains under suboptimal conditions (e.g. growth in medium containing moderate amount of sodium chloride) on their survival in some chemical and physical preservatives.

\section{Materials and Methods}

\subsection{Bacterial Strains}

Staphylococcus aureus strains used in this study were previously isolated by the author. The strains were isolated from raw milk from dairy processing plant, and from raw milk from dairy farm.

\subsection{Media and Chemicals}

Crude extract of Thymus vulgaris (extracted by hydrodistillation) was obtained from Systema Co. Ltd. (Amman, Jordan). Stock solution of ascorbic acid was freshly prepared before each use and sterilized by filtration through membrane filters $(0.45 \mathrm{um}$, Micron Separation Inc., Philadelphia, Pa., USA).

\subsection{Effect of $\mathrm{NaCl}$ on Survival of the Strains}

A $0.5 \mathrm{ml}$ of overnight grown bacterial culture was added to tubes containing $10 \mathrm{ml}$ nutrient broth plus $10 \% \mathrm{NaCl}$ or nutrient broth plus $15 \% \mathrm{NaCl}$. Inoculated tubes were incubated static at $37^{\circ} \mathrm{C}$ for $20 \mathrm{~h}$ or 5 days. Then, $0.5 \mathrm{ml}$ of the appropriate culture was added to flasks containing $30 \mathrm{ml}$ nutrient broth plus $20 \% \mathrm{NaCl}$, nutrient broth plus $0.3 \%$ Thymus vulgaris extract, or nutrient broth plus $0.1 \%$ ascorbic acid; and flasks were incubated static at $37^{\circ} \mathrm{C}$ for 4 days. For survival at low temperature, $0.5 \mathrm{ml}$ of the above mentioned bacterial cultures (i.e. bacterial cultures grown in nutrient broth plus $10 \% \mathrm{NaCl}$ or in nutrient broth plus $15 \% \mathrm{NaCl}$ ) were added to flasks containing $30 \mathrm{ml}$ of nutrient broth alone and incubated at $5^{\circ} \mathrm{C}$ for 12 days. At appropriate times, bacterial 
cultures $(0.1 \mathrm{ml})$ were diluted in $0.85 \% \mathrm{NaCl}$ and number of $S$. aureus cells was determined by plating on nutrient agar and incubation of plates at $37^{\circ} \mathrm{C}$ for $48 \mathrm{~h}$.

For control experiments, $0.5 \mathrm{ml}$ of the overnight grown bacterial culture was directly added to flasks containing $30 \mathrm{ml}$ nutrient broth plus $20 \% \mathrm{NaCl}$, nutrient broth plus $0.3 \%$ Thymus vulgaris extract, or nutrient broth plus $0.1 \%$ ascorbic acid; and flasks were incubated static at $37^{\circ} \mathrm{C}$ for 4 days. For growth at low temperature (control experiment), $0.5 \mathrm{ml}$ of the overnight grown bacterial culture was directly added to flask containing $30 \mathrm{ml}$ nutrient broth alone and incubated at $5^{\circ} \mathrm{C}$ for 12 days. Number of viable cells was enumerated as mentioned above.

\subsection{Statistical Analysis}

All experiments were done four times with consistent results. The log number of cells presented are the mean values and the standard error for these readings ranged from \pm 0.1 to \pm 0.2 . Student's $t$-test was used to determine the significant differences $(\mathrm{p}<0.05)$ among the different culture conditions.

\section{Results}

The isolated strains were tested; and the results shown are of representative strain from raw milk from dairy processing plant $(S$. aureus 5$)$ and of representative strain from raw milk from dairy farm $(S$. aureus 16$)$.

\subsection{Growth of $S$, aureus at Various Conditions (Control Experiments)}

The effect of various preservatives on $S$. aureus 5 and $S$. aureus 16 grown for $20 \mathrm{~h}$ in nutrient broth alone was examined (Table 1). Presence of $20 \% \mathrm{NaCl}$ in the medium

Table 1. Effect of incubation for $20 \mathrm{~h}$ in nutrient broth alone on survival of $S$. aureus 5 (a) and $S$. aureus 16 (b) in nutrient broth at various conditions.

(a)

\begin{tabular}{cccc}
\hline \multirow{2}{*}{ Growth conditions } & \multicolumn{2}{c}{ Log CFU/ml } & \% increase (decrease) in log \\
\cline { 2 - 3 } & $\mathrm{t}_{0}$ & $\mathrm{t}$ & $(6)$ \\
$\mathrm{nyBn}+20 \% \mathrm{NaCl}, 37^{\circ} \mathrm{C}$ & 7.0 & $6.6^{\mathrm{a}}$ & $(6)$ \\
$\mathrm{NB}+0.3 \%$ thyme extract, $37^{\circ} \mathrm{C}$ & 6.5 & $6.7^{\mathrm{a}}$ & 3 \\
$\mathrm{NB}+0.1 \%$ ascorbic acid, $37^{\circ} \mathrm{C}$ & 6.5 & $7.2^{\mathrm{a}}$ & 10 \\
$\mathrm{NB}, 5^{\circ} \mathrm{C}$ & 7.0 & $6.1^{\mathrm{b}}$ & $(13)$ \\
\hline
\end{tabular}

(b)

\begin{tabular}{cccc}
\hline \multirow{2}{*}{ Growth conditions } & \multicolumn{2}{c}{$\log \mathrm{CFU} / \mathrm{ml}$} & \multirow{2}{*}{$\begin{array}{c}\text { increase (decrease) in log } \\
\text { CFU } / \mathrm{ml}^{\mathrm{c}}\end{array}$} \\
\cline { 2 - 3 } $\mathrm{NB}+20 \% \mathrm{NaCl}, 37^{\circ} \mathrm{C}$ & 6.0 & $\mathrm{t}$ & $(23)$ \\
$\mathrm{NB}+0.3 \%$ thyme extract, $37^{\circ} \mathrm{C}$ & 6.1 & $6.6^{\mathrm{a}}$ & 11 \\
$\mathrm{NB}+0.1 \%$ ascorbic acid, $37^{\circ} \mathrm{C}$ & 6.1 & $7.4^{\mathrm{a}}$ & 21 \\
$\mathrm{NB}, 5^{\circ} \mathrm{C}$ & 6.2 & $5.5^{\mathrm{b}}$ & $(11)$ \\
\hline
\end{tabular}

${ }^{\mathrm{a}}$ Growth after 4 days. ${ }^{\mathrm{b}}$ Growth after 12 days. ${ }^{\mathrm{c}} \%$ increase (decrease) in $\log \mathrm{CFU} / \mathrm{ml}=100 \times(\log \mathrm{CFU} / \mathrm{ml}$ at the specified time-log $\mathrm{CFU} / \mathrm{ml}$ at time zero/log $\mathrm{CFU} / \mathrm{ml}$ at time zero). 
slightly decreased growth of $S$. aureus 5 , where the percentage of decrease in log number of cells after $4 \mathrm{~d}$ incubation was $6 \%$ (Table $1(\mathrm{a})$ ). The presence of $0.3 \% T$. vulgaris extract or $0.1 \%$ ascorbic acid in the medium slightly promoted growth of $S$. aureus 5 . The percentages of increase in log number of cells after $4 \mathrm{~d}$ incubation were $3 \%$ and $10 \%$, respectively.

Nearly similar results were obtained for S. aureus 16 (Table 1(b)). Presence of $20 \%$ $\mathrm{NaCl}$ in the medium decreased growth of this strain, but the percentage of decrease was more than that of $S$. aureus 5 . The presence of $0.3 \% T$. vulgaris extract or $0.1 \%$ ascorbic acid in the medium slightly promoted growth of $S$. aureus 16 . The percentages of increase in log number of cells after $4 \mathrm{~d}$ incubation were $11 \%$ and $21 \%$, respectively (Table $1(\mathrm{~b})$ ).

The effect of low temperature on growth of the tested $S$. aureus strains in nutrient broth alone is shown in Table 1. For both strains, the number of cells did not change after 8 days of incubation (data not shown), but slightly decreased after $12 \mathrm{~d}$ incubation at $5^{\circ} \mathrm{C}$.

\subsection{Effect of Growth in $\mathrm{NaCl}$ on Survival of $S$. aureus in Chemical Preservatives}

The effect of growth for $20 \mathrm{~h}$ in nutrient broth containing $10 \% \mathrm{NaCl}$ on survival of $S$. aureus strains at various conditions is presented in Table 2. Both strains showed a great increase in levels of survival at the tested conditions, but the percentage of increase in survival varied among the strains. $S$. aureus 5 showed greater increase in survival than S. aureus 16. S. aureus 5 cells grown for $20 \mathrm{~h}$ in nutrient broth containing $10 \%$ sodium chloride significantly survived more in nutrient broth plus $20 \% \mathrm{NaCl}$, nutrient broth plus $0.3 \%$ thyme extract or nutrient broth plus $0.1 \%$ ascorbic acid $(\mathrm{p}<0.05)$. The percentages of increase in log cell number after $4 \mathrm{~d}$ incubation were $19 \%, 40 \%$ and $48 \%$, respectively (Table 2(a)). This represents 25,13 and 4.8 fold, respectively, increase in $\log$ cell number compared to the survival of $S$. aureus 5 cells grown in nutrient broth alone and then subjected to these preservatives (Table 1(a) \& Table 2(a)). For $S$. aureus 16 treated under the same conditions, the percentages of increase (decrease) in log number of cells after $4 \mathrm{~d}$ incubation in nutrient broth plus $20 \% \mathrm{NaCl}$, nutrient broth plus $0.3 \%$ thyme extract or nutrient broth plus $0.1 \%$ ascorbic acid were $(10 \%), 34 \%$ and $40 \%$, respectively. This represents $2.3,3$ and 2 fold, respectively, increase in log cell number compared to the survival of $S$. aureus 16 cells grown in nutrient broth alone and subjected to these preservatives ( $\mathrm{p}<0.05)$ (Table 1(b) \& Table 2(b)).

Effect of growth for $20 \mathrm{~h}$ in nutrient broth containing $15 \% \mathrm{NaCl}$ on survival of $S$. aureus 5 is presented in Table 3 (a). Incubation of the tested strain under this condition also increased $(\mathrm{p}<0.05)$ the survival of the cells in nutrient broth plus $20 \% \mathrm{NaCl}$, nutrient broth plus $0.3 \%$ thyme extract or nutrient broth plus $0.1 \%$ ascorbic acid (Table 3 ). The percentages of increase in log cell number after $4 \mathrm{~d}$ incubation were $29 \%, 33 \%$ and $36 \%$, respectively (Table $3(\mathrm{a})$ ). For $S$. aureus 16 cells grown under the same conditions, nearly similar results were observed. The percentages of increase in log cell 
Table 2. Effect of incubation for $20 \mathrm{~h}$ in $\mathrm{NB}$ containing $10 \% \mathrm{NaCl}$ on survival of (a) S. aureus 5 and (b) $S$. aureus 16 .

(a)

\begin{tabular}{cccc}
\hline Growth conditions & Incubation time (d) & Log CFU/ml & $\begin{array}{c}\text { \% increase (decrease) in } \\
\log \mathrm{CFU} / \mathrm{ml}\end{array}$ \\
\hline $\mathrm{NB}+20 \% \mathrm{NaCl}, 37^{\circ} \mathrm{C}$ & 0 & 5.7 & - \\
& 1 & 6.9 & 21 \\
$\mathrm{NB}+0.3 \%$ thyme & 4 & 6.8 & - \\
extract, $37^{\circ} \mathrm{C}$ & 0 & 5.3 & 45 \\
& 1 & 7.7 & 40 \\
$\mathrm{NB}+0.1 \%$ ascorbic & 4 & 7.4 & - \\
acid, $37^{\circ} \mathrm{C}$ & 0 & 5.2 & 46 \\
& 1 & 7.6 & - \\
$\mathrm{NB}, 5^{\circ} \mathrm{C}$ & 4 & 7.7 & $(26)$ \\
\hline
\end{tabular}

(b)

\begin{tabular}{cccc}
\hline Growth conditions & Incubation time (d) & Log CFU/ml & $\begin{array}{c}\text { \% increase (decrease) in } \\
\text { log CFU } / \mathrm{ml}\end{array}$ \\
\hline $\mathrm{NB}+20 \% \mathrm{NaCl}, 37^{\circ} \mathrm{C}$ & 0 & 5.8 & - \\
& 4 & 5.2 & - \\
$\mathrm{NB}+0.3 \%$ thyme & 0 & 5.3 & 34 \\
extract, $37^{\circ} \mathrm{C}$ & 4 & 7.1 & - \\
& & & 40 \\
$\mathrm{NB}+0.1 \%$ ascorbic & 0 & 5.2 & - \\
acid, $37^{\circ} \mathrm{C}$ & 4 & 7.3 & $(15)$ \\
& & & \\
$\mathrm{NB}, 5^{\circ} \mathrm{C}$ & 0 & 6.0 & 5.1 \\
\hline
\end{tabular}

number after $4 \mathrm{~d}$ incubation in nutrient broth plus $20 \% \mathrm{NaCl}$, nutrient broth plus $0.3 \%$ thyme extract or nutrient broth plus $0.1 \%$ ascorbic acid were $0 \%, 30 \%$ and $34 \%$, respectively, (p < 0.05) (Table 3(b)).

Increasing the incubation period of $S$. aureus in nutrient broth containing $10 \%$ sodium chloride to 5 days further increased the survival of the tested strains in nutrient broth plus $20 \% \mathrm{NaCl}$, nutrient broth plus $0.3 \%$ thyme extract or nutrient broth plus $0.1 \%$ ascorbic acid $(\mathrm{p}<0.05)$. For $S$. aureus 5 , the percentages of increase in log cell number after $4 \mathrm{~d}$ incubation in these preservatives were $30 \%, 56 \%$ and $67 \%$, respectively (Table 4(a)). This represents 36, 19 and 6.7 fold, respectively, increase in log cell number compared to the survival of $S$. aureus 5 cells grown in nutrient broth alone and subjected to these preservatives (Table 1(a) \& Table 4(a)). Also, similar results were obtained for $S$. aureus 16 . The percentages of increase in log cell number after $4 \mathrm{~d}$ incubation in nutrient broth plus $20 \% \mathrm{NaCl}$, nutrient broth plus $0.3 \%$ thyme extract or 
Table 3. Effect of incubation for $20 \mathrm{~h}$ in $\mathrm{NB}$ containing $15 \% \mathrm{NaCl}$ on survival of (a) $S$. aureus 5 and (b) $S$. aureus 16 .

(a)

\begin{tabular}{cccc}
\hline Growth conditions & Incubation time $(\mathrm{d})$ & Log CFU/ml & $\begin{array}{c}\text { \% increase (decrease) in } \\
\log \mathrm{CFU} / \mathrm{ml}\end{array}$ \\
\hline $\mathrm{NB}+20 \% \mathrm{NaCl}, 37^{\circ} \mathrm{C}$ & 0 & 5.5 & - \\
& 1 & 5.9 & 29 \\
$\mathrm{NB}+0.3 \%$ thyme & 4 & 7.1 & - \\
extract, $37^{\circ} \mathrm{C}$ & 0 & 5.4 & 44 \\
$\mathrm{NB}+0.1 \%$ ascorbic & 1 & 7.8 & 33 \\
acid, $37^{\circ} \mathrm{C}$ & 0 & 7.2 & - \\
& 1 & 5.3 & 40 \\
$\mathrm{NB}, 5^{\circ} \mathrm{C}$ & 4 & 7.4 & 36 \\
& 0 & 7.2 & $(8)$ \\
\hline
\end{tabular}

(b)

\begin{tabular}{cccc}
\hline Growth conditions & Incubation time (d) & Log CFU/ml & $\begin{array}{c}\text { \% increase (decrease) in } \\
\log \mathrm{CFU} / \mathrm{ml}\end{array}$ \\
\hline $\mathrm{NB}+20 \% \mathrm{NaCl}, 37^{\circ} \mathrm{C}$ & 0 & 5.6 & - \\
& 4 & 5.6 & - \\
$\mathrm{NB}+0.3 \%$ thyme & 0 & 5.4 & 30 \\
extract, $37^{\circ} \mathrm{C}$ & 4 & 7.0 & - \\
& & & 34 \\
$\mathrm{NB}+0.1 \%$ ascorbic & 0 & 5.3 & - \\
acid, $37^{\circ} \mathrm{C}$ & 4 & 7.1 & $(9)$ \\
& & & \\
$\mathrm{NB}, 5^{\circ} \mathrm{C}$ & 12 & 5.5 & 5.0 \\
\hline
\end{tabular}

nutrient broth plus $0.1 \%$ ascorbic acid were $4 \%, 42 \%$ and $54 \%$, respectively (Table $4(\mathrm{~b}))$.

\subsection{Effect of Growth in $\mathrm{NaCl}$ on Survival of $S$. aureus at Low Temperature}

S. aureus 5 and $S$. aureus 16 cells grown for $20 \mathrm{~h}$ in nutrient broth containing $10 \% \mathrm{NaCl}$ did not survive more in nutrient broth at low temperature $\left(5^{\circ} \mathrm{C}\right)($ Table 2$)$. However, growth of the tested strains for $20 \mathrm{~h}$ in nutrient broth containing $15 \% \mathrm{NaCl}$ or for $5 \mathrm{~d}$ in nutrient broth containing $10 \% \mathrm{NaCl}$ slightly increased $(\mathrm{p}<0.05)$ the survival of $S$. aureus 5 and $S$. aureus 16 cells in nutrient broth at low temperature (Table $3 \&$ Table 4 ).

\section{Discussion}

S. aureus can be found in raw milk, on surfaces of fresh meat, poultry and fish, and on skin of humans. Chemical preservatives are usually added to inhibit growth of bacteria 
Table 4. Effect of incubation for 5 days in $\mathrm{NB}$ containing $10 \% \mathrm{NaCl}$ on survival of (a) S. aureus 5 and (b) $S$. aureus 16 .

(a)

\begin{tabular}{cccc}
\hline Growth conditions & Incubation time $(\mathrm{d})$ & Log CFU/ml & $\begin{array}{c}\text { \% increase (decrease) in } \\
\log \mathrm{CFU} / \mathrm{ml}\end{array}$ \\
\hline $\mathrm{NB}+20 \% \mathrm{NaCl}, 37^{\circ} \mathrm{C}$ & 0 & 6.3 & - \\
& 1 & 7.6 & 20 \\
$\mathrm{NB}+0.3 \%$ thyme & 4 & 8.2 & 30 \\
extract, $37^{\circ} \mathrm{C}$ & 0 & 5.9 & - \\
& 1 & 8.4 & 56 \\
$\mathrm{NB}+0.1 \%$ ascorbic & 4 & 9.2 & - \\
acid, $37^{\circ} \mathrm{C}$ & 0 & 5.8 & 43 \\
& 1 & 8.3 & 67 \\
$\mathrm{NB}, 5^{\circ} \mathrm{C}$ & 4 & 9.7 & - \\
& 12 & 6.1 & $(10)$ \\
\hline
\end{tabular}

(b)

\begin{tabular}{cccc}
\hline Growth conditions & Incubation time (d) & Log CFU/ml & $\begin{array}{c}\text { increase (decrease) in } \\
\log \mathrm{CFU} / \mathrm{ml}\end{array}$ \\
\hline $\mathrm{NB}+20 \% \mathrm{NaCl}, 37^{\circ} \mathrm{C}$ & 0 & 6.4 & - \\
& 4 & 6.7 & - \\
$\mathrm{NB}+0.3 \%$ thyme & 0 & & 42 \\
extract, $37^{\circ} \mathrm{C}$ & 4 & 6.1 & - \\
& & 8.7 & 54 \\
$\mathrm{NB}+0.1 \%$ ascorbic & 0 & & - \\
acid, $37^{\circ} \mathrm{C}$ & 4 & 6.1 & $(7)$ \\
& & 9.4 & \\
$\mathrm{NB}, 5^{\circ} \mathrm{C}$ & 0 & 5.9 & 5.5 \\
\hline
\end{tabular}

and extend shelf life of foods. However, food and food products are sometimes minimally processed, which may allow survival of bacterial cells and induce increased resistance to various preservatives.

\subsection{Effect of Growth in $\mathrm{NaCl}$ on Survival of $S$, aureus in Chemical Preservatives}

In this study, growth of $S$. aureus strains for $20 \mathrm{~h}$ in nutrient broth containing $10 \%$ or $15 \% \mathrm{NaCl}$ increased the subsequent survival of the strains in nutrient broth containing various preservatives (e.g. $20 \% \mathrm{NaCl}, 0.3 \%$ thyme extract, or $0.1 \%$ ascorbic acid). These findings are consistent with other studies on Salmonella spp. and E. coli. It has been reported that E. coli $\mathrm{O} 157: \mathrm{H} 7$ cells that were adapted to acid (by culturing for one to two doublings at $\mathrm{pH}$ 5) had an increased resistance to lactic acid and survived better in shredded dry salami ( $\mathrm{pH} \mathrm{5)}$ and apple cider ( $\mathrm{pH} \mathrm{3.4)} \mathrm{[7].} \mathrm{Also,} \mathrm{in} \mathrm{Salmonella} \mathrm{typhimu-}$ rium, acid adaptation induced cross-protection against environmental stresses such as 
heat, salt and surface-active agents [8], and in E. coli K12, prior exposure to acidic conditions increased survival of cells at low $\mathrm{pH}[9]$.

Mild stresses can trigger a general stress response system in the bacterial cell causing increased resistance to preservatives and environmental factors. The Rpo $S$ sigma factor is the regulator of the general stress in E. coli and Salmonella spp. when acid shock or starvation are encountered [10]. In $S$. aureus, a similar stress response may be triggered alone or in combination with other systems.

In this study, the tested strains showed increased survival in various preservatives after growth in $10 \%$ or $15 \% \mathrm{NaCl}$, but the level of increase was greater in $S$. aureus 5 than in $S$. aureus 16. S. aureus 16 was isolated from raw milk from dairy farm while the former strain was isolated from raw milk from dairy processing plant, and may be therefore exposed to other stresses (e.g. long time at high temperature) before arrival to the processing plant. Similar findings were reported by Abu-Ghazaleh et al. [11], and AbuGhazaleh [12] who reported that genetic and environmental factors influence the tolerance of food poisoning bacteria to heat and chemical preservatives. Also, Leyer et al. [7] emphasized the need to take into account the previous history of strains used in food challenge studies which could affect their survival in the environment.

\subsection{Effect of Growth in NaCl on Survival of $S$. aureus at Low Temperature}

In this study, growth of the tested strains in $\mathrm{NaCl}(10 \%$ or $15 \%)$ did not increase or slightly increased survival of the strains at low temperature $\left(5^{\circ} \mathrm{C}\right)$. Studies on other types of bacteria (e.g. E. coli O157:H7) have showed that exposure of the strain to low $\mathrm{pH}$ (such as beef gravy medium containing $5 \% \mathrm{NaCl}, \mathrm{pH} 4.5$ ), enhanced survival of cells at $7{ }^{\circ} \mathrm{C}$ compared to $22^{\circ} \mathrm{C}$ [13]. However, the present study examined survival of $S$. aureus strains at lower temperature $\left(5^{\circ} \mathrm{C}\right)$. Also, $S$. aureus may be less tolerant to low temperature than E. coli.

\section{Conclusion}

This study has showed that growth of $S$. aureus strains at suboptimal conditions (e.g. $10 \%$ or $15 \% \mathrm{NaCl}$ ) enhances their survival in chemical preservatives. This suggests that although minimal processing may increase the shelf life of foods, it causes concerns in some foods that contain food poisoning bacteria, such as $S$. aureus, that can adapt to suboptimal growth conditions and survive in these foods.

\section{References}

[1] Balaban, B. and Rasooly, A. (2000) Staphylococcal Enterotoxins. International Journal of Food Microbiology, 61, 1-10. http://dx.doi.org/10.1016/S0168-1605(00)00377-9

[2] Hennekinne, J.A., De Buyser, M.L. and Dragacci, S. (2012) Staphylococcus aureus and Its Food Poisoning Toxins: Characterization and Outbreak Investigation. FEMS Microbiology Reviews, 36, 815-836. http://dx.doi.org/10.1111/j.1574-6976.2011.00311.x

[3] Jay, J.M. (2000) Modern Food Microbiology. 6th Edition, Chapman and Hall, New York. http://dx.doi.org/10.1007/978-1-4615-4427-2 
[4] Dinges, M.M., Orwin, P.M. and Schlievert, P.M. (2000) Exotoxins of Staphylococcus aureus. Clinical Microbiology Reviews, 13, 16-34.

http://dx.doi.org/10.1128/CMR.13.1.16-34.2000

[5] Evenson, M.L., Hinds, M.W., Bernstein, R.S. and Bergdoll, M.S. (1998) Estimation of Human Dose of Staphylococcal Enterotoxin A from a Large Outbreak of Staphylococcal Food Poisoning Involving Chocolate Milk. International Journal of Food Microbiology, 7, 311316. http://dx.doi.org/10.1016/0168-1605(88)90057-8

[6] Jawetz, E., Melnick, J.L. and Adelberg, E.A. (1984) Modern Microbiology. 16th Edition, Lange, Los Altos.

[7] Leyer, G.J., Wang, L. and Johnson, E.A. (1995) Acid Adaptation of Escherichia coli O157:H7 Increases Survival in Acidic Foods. Applied and Environmental Microbiology, 61, 3752-3755.

[8] Leyer, G.J. and Johnson, E.A. (1993) Acid Adaptation Induces Cross Protection against Enviromental Stresses in Salmonella typhimurium. Applied and Environmental Microbiology, 59, $1842-1847$.

[9] Goodson, M. and Rowbury, R.J. (1989) Habituation to Normally Lethal Acidity by Prior Growth of Escherichia coli at a Sub-Lethal Acid pH Value. Letters in Applied Mircobiology, 8, 77-79. http://dx.doi.org/10.1111/j.1472-765X.1989.tb00227.x

[10] Abee, T. and Wouters, J.A. (1999) Microbial Stress Response in Minimal Processing. International Journal of Food Microbiology, 50, 65-91. http://dx.doi.org/10.1016/S0168-1605(99)00078-1

[11] Abu-Ghazaleh, B.M., Humphrey, T.J., Smith, D.G. and Rowbury, R.J. (1989) The ColV, I-K94 Plasmid and Heat Sensitivity of Escherichia coli. Letters in Applied Microbiology, 9, 75-77. http://dx.doi.org/10.1111/j.1472-765X.1989.tb00295.x

[12] Abu-Ghazaleh, B.M. (2000) Inhibition of Aeromonas caviae and A. sobria by Sodium Chloride, Citric Acid, Ascorbic Acid, Potassium Sorbate and Extracts of Thymus vulgaris. Japanese Journal of Infectious Diseases, 53, 111-115.

[13] Uyttendaele, M., Taverniers, I. and Debevere, J. (2001) Effect of Stress Induced by Suboptimal Growth Factors on Survival of Escherichia coli O157:H7. International Journal of Food Mircobiology, 66, 31-37. http://dx.doi.org/10.1016/S0168-1605(00)00509-2

\section{Submit or recommend next manuscript to SCIRP and we will provide best service for you:}

Accepting pre-submission inquiries through Email, Facebook, LinkedIn, Twitter, etc.

A wide selection of journals (inclusive of 9 subjects, more than 200 journals)

Providing 24-hour high-quality service

User-friendly online submission system

Fair and swift peer-review system

Efficient typesetting and proofreading procedure

Display of the result of downloads and visits, as well as the number of cited articles

Maximum dissemination of your research work

Submit your manuscript at: http://papersubmission.scirp.org/ 